${ }^{5}$ McGowan JE, Bratton L, Klein JO, Finland M. Bacteremia in febrile children seen in a "walk-in" pediatric clinic. N Engl f Med 1973;288: 1309-12.

${ }^{6}$ Myers MG, Wright PF, Smith AL, Smith DH. Complications of occult pneumococcal bacteremia in children. $\mathcal{F}$ Pediatr $1974 ; 84: 656-60$.

7 Teele DW, Pelton SI, Grant MJA, et al. Bacteremia in febrile children under 2 years of age: results of cultures of blood of 600 consecutive febrile children seen in a "walk-in" clinic. $\mathcal{f}$ Pediatr 1975;57:861-7.

${ }^{8}$ McCarthy PL, Grundy GW, Spiegel SZ, Dolan TF. Bacteremia in children: an out-patient clinical review. Pediatrics 1976;57:861-7.

${ }^{9}$ Bratton L, Teele BW, Klein JO. Outcome of unsuspected pneumococcemia in children not initially admitted to hospital. $\mathcal{F}$ Pediatr $1977 ; 90$ : 703-6.

${ }^{10}$ McCarthy PL, Jekel JF, Dolan TF. Temperature greater than or equal to $40^{\circ} \mathrm{C}$ in children less than 24 months of age: a prospective study. Pediatrics 1977;59:663-7.

11 Hamrick HJ, Murphy TF. Bacteremia in 28 ambulatory children. Clin Pediatr (Phila) 1978;17:109-12.

12 Feder HM. Occult pneumococcal bacteremia and the febrile infant and young child. A clinical review. Clin Pediatr (Phila) 1980;19:457-62.

13 Baron MA, Fink HD. Bacteremia in private pediatric practice. Pediatrics $1980 ; 66: 171-4$.

14 McCarthy PL, Dolan TF. Hyperpyrexia in children : eight year emergency room experience. $A m \mathcal{F}$ Dis Child 1976;130:849-51.

15 Winchester TD, Todd JK, Roe MH. Bacteremia in hospitalized children. Am $¥$ Dis Child 1977;131:753-8.

${ }^{16}$ Marshall WC, Bamforth JSG. The impact of pneumococcal infections in paediatrics. In: Lambert HP, Caldwell ADS, eds. Pneumonia and pneumococcal infections. Royal Society of Medicine International Congress and Symposium Series 1980;27:103-10.

17 Austrian R. Current states of bacterial pneumonia with especial reference to pneumococcal infection. $\mathcal{F}$ Clin Pathol 1968;21,suppl 2:93-7.

18 Bullowa JGM. The management of the pneumonias. New York: Oxford University Press, 1937.

19 Bille J, Glanser MP, Freedman LR. Risk of death in adult pneumococcal bacteraemia. In: Lambert HP, Caldwell ADS, eds. Pneumonia and pneumococcal infections. Royal Society of Medicine Congress and Symposium Series 1980;27:47-52.

20 Waskerwitz S, Berkelhamer JE. Outpatient bacteremia: clinical findings in children under two years with initial temperatures $39.5^{\circ} \mathrm{C}$ or higher. 7 Pediatr 1981;99:231-3.

${ }^{21}$ Cole FS, Sarayan JA, Smith AL. Risk of recurrence of occult pneumococcal bacteremia. $\mathcal{F}$ Pediatr 1981;99:99-104.

${ }^{22}$ Hilleman MR, Woodhour AF, Weible RW, Vella RP, McClean AA, Carlson AF. Vaccination against pneumococcal infections. In: Lambert
HP, Caldwell ADS, eds. Pneumonia and pneumococcal infections. Royal Society of Medicine Congress and Symposium Series 1980;27:47-52.

${ }^{23}$ Lewin GA, Nakasato C, Overturf GD. Bacteremia in outpatients. Clin Res $1976 ; 24: 176 \mathrm{~A}$

${ }^{24}$ Rutter N, Smales ORC. Role of routine investigations in children presenting with their first febrile convulsion. Arch Dis Child 1977;52:188-91.

${ }^{25}$ Asnes RS, Novick LF, Nedis J, Nguyen NL. The first febrile seizure: a study of current pediatric practice. $\mathcal{F}$ Pediatr 1975;87:485-8.

${ }^{26}$ Wolf SM. Laboratory evaluation of the child with a febrile convulsion. Pediatrics 1978;62:1074-6.

27 National Institutes of Health Consensus Statement. Febrile seizures : longterm management of children with fever-associated seizures. Pediatrics 1980;66:1009-13.

${ }^{28}$ Jaffe M, Bar-Joseph G, Tirosh E. Fever and convulsions-indications for laboratory investigations. Pediatrics $1981 ; 67: 729-31$.

29 Todd JK. Childhood infections: diagnostic value of peripheral white cell and differential cell counts. Am F Dis Child 1974;127:810-6.

${ }^{30}$ Murray DI, Sonana J, Seidel JS, Yoshimori RN, Imagawa DT, St Geme $\mathrm{JW}$. Relative importance of bacteremia and viremia in the course of acute fevers of unknown origin in outpatient children. Pediatrics $1981 ; 68$. 159-60.

${ }^{31}$ Loda FA, Collier AM, Strangert MD, et al. Occurrence of Diplococcus pneumoniae in the upper respiratory tract of children. $\mathcal{F}$ Pediatr 1975; 87:1087-93.

32 Teele DW, Marshall R, Klein JO. Unsuspected bacteremia in young children. A common and important problem. Pediatr Clin North Am $1979 ; 26: 773-84$

${ }^{33}$ Rischer GW, Brenz RW, Alden ER, Beckwith JB. Lumbar punctures and meningitis. Am $\mathcal{F}$ Dis Child 1975;129:590-2.

34 Santoshan M, Moxon ER. Detection and quantitation of bacteremia in childhood. 7 Pediatr 1977;91:719-21.

${ }^{35}$ Sullivan TD, La Scolea LJ, Neter E. Relationship between the magnitude of bacteremia in children and the clinical disease. Pediatrics 1982;69: 699-702.

${ }^{36}$ Teele DW, Dashefsky B, Rakuson T, Klein JO. Meningitis after lumbar puncture in children with bacteremia. N Engl f Med 1981 ;305:1079-81.

${ }^{37}$ Petersdorf RG, Swarner DR, Garcia M. Studies on the pathogenesis of meningitis. II Development of meningitis during pneumococcal bacteremia. $\mathcal{f}$ Clin Invest $1962 ; 41: 320-7$.

${ }^{38}$ Aarimaa T, Peltola $\mathrm{H}$, Ruuskanen $\mathrm{O}$. Pneumococcaemia complicated by meningitis. Arch Dis Child 1982;57:392-4.

${ }^{39}$ Smith AL. Childhood bacteremia. N Engl f Med 1973;288:1309-12.

(Accepted 28 October 1982)

\title{
Letters to a Young Doctor
}

\section{Careers outside hospital and general practice}

\section{PHILIP RHODES}

A great advantage of qualifying in medicine is that so many different careers are then open to you. There are between 50 and 60 specialties, so that a satisfying career is available for virtually every taste. There is no need for blinkered vision, believing that there are only the two mainstreams of general practice and hospital medicine. It is perhaps unfortunate that most graduates think only of these, though there is tremendous variety in each of them. Yet not everyone is happy in hospital medicine or general practice, nor is everyone successful in them. The reason may be a lack of motivation caused by inadequate

\section{University of Southampton, Southampton}

PHILIP RHODES, MB, FRCS, professor of postgraduate medical education, and dean of graduate medicine for the Wessex region understanding of oneself and one's vocation. You should not feel like a failure in recognising that the classic traditions of medical practice are not for you. You must recognise the immense complexity of medicine today in both its internal and its external relations. Doctors are needed at many points in the machinery to keep the whole of it functioning.

It is a curse of medicine that an informal snobbish hierarchy has developed, so that some occupations in medicine may appear intrinsically more important and worth while than others. Medicine is probably no worse in this than other vocations, but it may result in a scramble for places at the top of the hierarchy while other parts lack the manpower for their proper purposes, which have their place and importance. Indeed, the mainstream of medicine may very well depend on medical education, administration, journalism and communication, the pharmaceutical industry, military service, and many other activities.

In 1982 there were relative shortages of manpower in general 
practice; all branches of pathology except haematology; radiology; radiotherapy and oncology; ear, nose, and throat surgery; ophthalmology; clinical pharmacology; and others. Service in one or other of these would often be more socially valuable than attempting to struggle into the ranks of general physicians, surgeons, and obstetricians and gynaecologists, where competition may be unnecessarily fierce and unrewarding. Satisfying and valuable careers are to be had in all of these shortage specialties. They are all important in the nexus of medicine.

\section{Basic medical sciences}

The basic medical sciences of anatomy, physiology, biochemistry, psychology, genetics, and sociology as applied to medicine all lack teachers who are medically qualified. Together with pharmacology, these subjects are taught more and more to medical students by scientists, none of whom have clinical experience and so must teach their subjects as pure science. Medically qualified teachers see the basic sciences more in relation to patients because they have had clinical experience. This is attractive to medical students, who see medicine as applied science and want what they learn of the basic medical sciences to be relevant to their future work, which is more likely to be clinical than not.

Thus, medically qualified teachers have an important role to play in bridging the concepts of the many separate disciplines. They can help to motivate students to learn the basic medical sciences because they witness its relevance. I do not denigrate the real contribution of scientists, but they need doctors in their midst to leaven their teaching. This helps to keep the eyes of every teacher on the main task of undergraduate teaching in medicine, which is to prepare students for clinical work and to understand its basis. This needs medical teachers who are devoted to the twin causes of their subject and basic medical education, which cannot be sustained purely by a stream of junior doctors who may revert temporarily to a basic science to work for part I of their higher clinical diplomas.

\section{Medical education}

There is now a demand for the study of medical education in its own right and not linked to a specific subject. Education and its techniques in imparting knowledge, skills, and attitudes and in assessment are of more than passing interest. They are central to the functions of medical schools, faculties, and universities, and all other medical educational bodies such as royal colleges and faculties, and even of the General Medical Council and the councils for postgraduate medical education. In medicine education has developed haphazardly-in an almost amateur fashion. It now needs professionals to take heed of advances in educational method and theory outside medicine and relate them to the specific requirements of medicine, and also to contribute to general education elsewhere. Many of the professionals will be non-medical, but they need to co-operate with medical professionals too, as in many other disciplines.

In the next article I shall discuss a career in community medicine.

\title{
Lesson of the Week
}

\section{Leg ulcers that do not heal}

\author{
J S ACKROYD, A E YOUNG
}

We report on three patients to illustrate the different ways in which malignancy may be neglected or misdiagnosed in a skin ulcer of long duration.

\section{Case reports}

Case 1-A 63 year old Portuguese man presented in 1976 complaining of recurrent ulceration of his foot. When he was 7 years old his foot was crushed under a stone, and he had had a subtalar amputation. The stump was first ulcerated in 1973 but healed when new boots were fitted. In 1974 diabetes mellitus was diagnosed and was controlled with diet and chlorpropamide tablets. In 1975 he had numb patches on one hand and on his face that were thought to be due to mono-

St Thomas's Hospital, London SE

J S ACKROYD, FRCS, honorary senior registrar in surgery

A E YOUNG, MCHIR, FRCS, consultant surgeon
A skin ulcer that fails to heal within four months should be biopsied

neuritis multiplex secondary to diabetes. He was also a heavy smoker. At admission his diabetes was poorly controlled, and he had an infected shallow ulcer on the dorsum of his amputation stump. Blood pressure, measured by the Doppler technique, was normal at the ankle, but on arteriography his arteries were diffusely calcified, with only the anterior tibial artery filling below the popliteal trifurcation. His ulcer was thought to be due to a combination of trauma and diabetes, and possibly ischaemic disease. He returned to Portugal without further treatment and reappeared in 1979; he still had the ulcer. A biopsy specimen showed a moderately differentiated squamous cell carcinoma. His leg was amputated below the knee.

Case 2-In 1976 a 71 year old woman presented with a short history of an ulcer on the posterolateral aspect of her calf. Excision and graft were advised, but she failed to attend because 